\title{
送電用鋼管単柱鉄塔の座屈耐力に関する研究 STUDY ON BUCKLING STRENGTH OF MONO-POLE FOR TRANSMISSION STEEL TOWERS
}

\author{
飯田 健*, 宮原幸二**, 深沢 隆***, 石田交広*** \\ Takeshi IIDA, Koji MIYAHARA, Takashi FUKASAWA \\ and Tomohiro ISHIDA
}

\begin{abstract}
The purpose of this paper is to establish a method for evaluating the full plastic strength of mono-pole steel towers instead of the normal yield strength. The bending tests on small models of partial towers are performed to prove the effectiveness of the nonlinear analysis by comparing with the previously obtained empirical results. The relation between the buckling strength and radius thickness ratio (D/t) are quantitatively evaluated together with the P- $\Delta$ effects. Also, this evaluation is ensured through the loading tests on a half-scale tower; the critical limit of $\mathrm{D} / \mathrm{t}$ for maintaining the full plastic strength is found: $\mathrm{D} / \mathrm{t} \leqq 33500 / \sigma_{\mathrm{y}}$, and the allowable deformation of its top is $3 \%$ of the height.
\end{abstract}

Keywords : Mono-ploe, Full plastic moment, Limitation of diameter-to-thickness ratio, Limitation of displacement 鋼管単柱，全塑性モーメント，径厚比制限，変位制限

\section{1.はじめに}

近年の都市部周辺における送電用鉄塔を取り巻く環境は,市街化の 進展にともない鉄塔用敷地の確保が難しく,都市景観に調和した鉄塔 形状への要望の増加などの理由により, 架空送電線のルート確保は, ますます厳しくなっている。このような状況に対処する一方策とし て, 鉄塔の幅 (以後, 根開きと呼ぶ) を小さく抑えることができ，か つ, シンプルな形状である鋼管単柱鉄塔（図 1 , 以後, 鋼管単柱と呼 ぶ）が従来より適用されている。しかし，鋼管単柱は，トラス型鉄塔 と比較して重量が重く, 建設費が高いため, そのコスト低減が求めら れている。

過去に実施された骨組レベルの座屈耐力試験1では, 鋼管単柱の方 がトラス型鉄塔2231にに比べ,材料の高まりを除いた無次元化耐力で評価 した場合の最大耐力の設計荷重（トラス型鉄塔では座屈荷重 $\mathrm{N}_{\mathrm{cr}}$, 鋼 管単柱では降伏モーメント $\mathrm{M}_{\mathrm{y}}$ ) に対する上昇率が大きいとの知見が 得られている。これは, 図 2 のとおり, 水平荷重 HLが加わった際の 部材に発生する支配的な応力は, トラス型鉄塔では軸力Nであるのに 対し，銅管単柱では曲げモーメント Mであり，軸力が支配的である トラス型鉄塔の構成部材は, 降伏軸力 $\mathrm{N}_{\mathrm{y}}$ 以前に座屈する（図 $2(\mathrm{a})$ の (1)）のに対し，曲げモーメントが作用する場合は，鋼管の径厚比（D/ $\mathrm{t}, \mathrm{D}$ : 鋼管径, $\mathrm{t}$ : 鋼管板厚) が小さければ, 断面の最外縁が降伏し
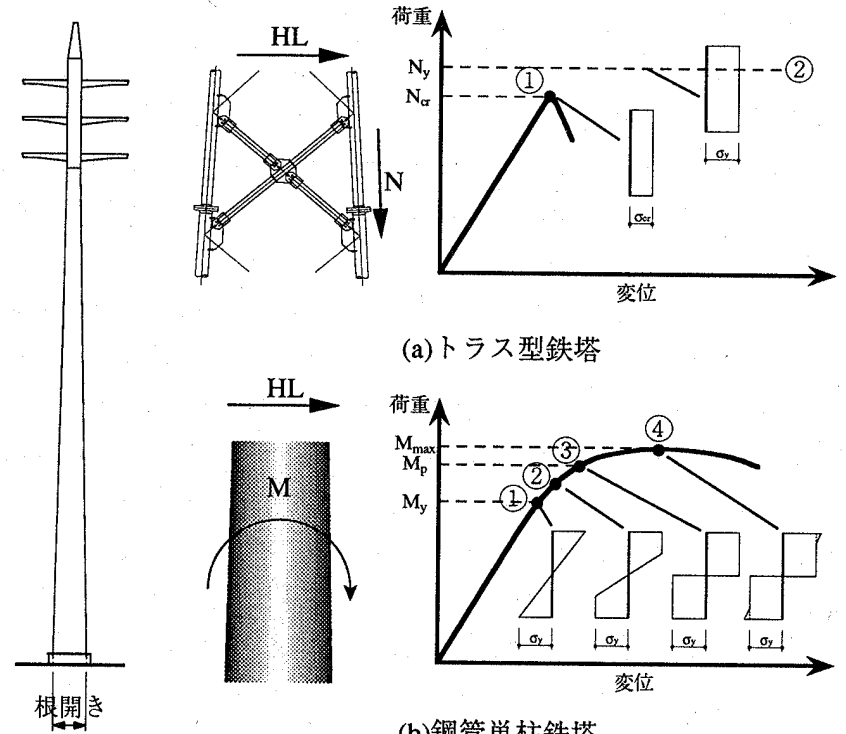

(a)トラス型鉄塔
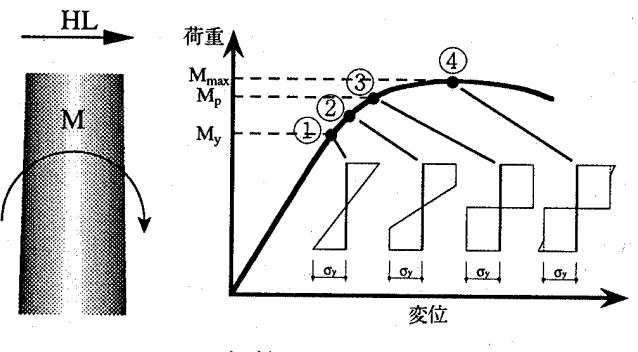

(b)鋼管単柱鉄塔

た状態 $\left(\mathrm{M}_{\mathrm{y}}\right)$ においても，断面のほとんどが弾性範囲（図 2 (b)の(1)） にあり, 余力を残しているためである。さらに, 径厚比が十分が小さ ければ，全断面が降伏した状態（全塑性モーメント $\mathrm{M}_{\mathrm{p}}$, 図 2 (b), (3))

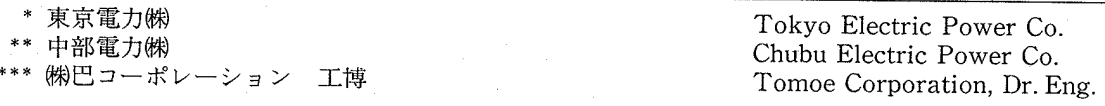


に達した後も素材のひずみ硬化により荷重は増大する。この径厚比と 最大曲げモーメントの関係については, 越智, 最相, 黒羽4による製 管のままの鋼管を対象とした既往の実験結果を整理した報告があり， 定量的に言及されている。しかしながら, 送電用鉄塔に一般的に施さ れる溶融亜鉛めっき処理をした鋼管 (以後, めっき鋼管と呼ぶ) を対 象とした径厚比と最大曲げモーメントの関係に言及した例はない。

また, 建築構造物は仕上げ材の脱落防止, 居住性等の観点から層間 変形角の変形制限が設けられているが,送電用鉄塔の場合は特に規定 は設けられていない。鋼管単柱では, 根開きがトラス型鉄塔と比べ小 さいことから, 水平力に対する剛性は低く, 水平変位 $\Delta$ 大ききくなる ことが考えられる。これにより，一般的に言われる $\mathrm{P} \Delta$ 効果に伴い, 鉛 直方向成分荷重 $\times$ 水平変位に相当する付加曲げモーメントが増大し, 座屈耐力に影響を及ぼすことが懸念される。送電用鋼管単柱鉄塔を対 象に,このP $\Delta$ 効果の座屈耐力に及ほす影響について定量的に言及し た研究は筆者らの知る限りないのが実状である。

このことから, 本研究は, まず最初にめっき鋼管の縮小部分モデル 部材による曲げ耐力試験を行い, 曲げ変形性状を定量的に把握し，そ の試験結果との対比によりシェル要素を用いた非線形解析手法の有効 性を確認する。次に有効性を確認した非線形解析手法を用いて, 径厚 比を変化させた縮小部分モデル部材を対象に, 座屈耐力と径厚比との 関係を把握し, 終局耐力である全塑性モーメントを確保するための径 厚比制限の検討を行う。さらに, 実規模鋼管単柱鉄塔を対象に非線形 解析を行い, P $\Delta$ 効果の最大耐力に及ほす影響を定量的に把握し, 変 位制限値を設定する。最後に，実鉄塔を模擬した $1 / 2$ スケールの鋼管 単柱鉄塔の載荷試験を行い, 検討結果の有効性を確認する。

\section{2. 縮小部分モデル部材曲げ耐力試験}

\section{1 試験概要}

径厚比が大きい鋼管の曲げモーメントによる局部座屈挙動を把握す るために, 径厚比を変化させた縮小部分モデル部材による曲げ耐力試 験を実施し, 後述する本研究で用いる非線形解析手法の有効性を検証 する。

試験体および試験装置概要を図 3 に示す。試験体の端部はべースプ レートを溶接し，反力骨組へボルトにより固定する。試験体は，材長 $\mathrm{L}=1500 \mathrm{~mm}$, 材質 SS400 とし, 溶融亜鉛めっきを施す。鋼管サイズは 鋼構造設計規準 s)圧縮材を対象とした径厚比制限值（D/t $\leqq 23500 /$ $\left.\sigma_{y}=23500 / 235=100\right)$ である $\phi 300 \times 3.2 （ \mathrm{D} / \mathrm{t}=93.8 ）$ と径厚比を大きく した $\phi 300 \times 2.3(\mathrm{D} / \mathrm{t}=130)$ の 2 種類とする。また, 文献 6 では, 溶 融严鉛めっき鋼管を対象に,(1)式で表される降伏応力度および径厚比 を含んだパラメータ $\alpha_{c}$ と耐力・変形能力と強い相関関係があること が示されて扔り, 本研究においてもパラメー夕 $\alpha_{c}$ を用いて最大耐力 の整理を行う。

$$
\begin{aligned}
& \alpha_{\mathrm{c}}=\frac{\mathrm{E}}{(\mathrm{D} / \mathrm{t}) \cdot \sigma_{\mathrm{y}}} \\
& \text { ここで, } \quad \mathrm{E}: \text { ヤング係数 }\left(\mathrm{N} / \mathrm{mm}^{2}\right) \\
& \sigma_{\mathrm{y}}: \text { 降伏応力度 }\left(\mathrm{N} / \mathrm{mm}^{2}\right)
\end{aligned}
$$

なお，文献 6 ) ではパラメー夕 $\alpha_{c}$ が小さい領域（およそ5以下）で は非対称座屈が生じるとしている。今回設定した鋼管のパラメー夕 $\alpha_{c}$

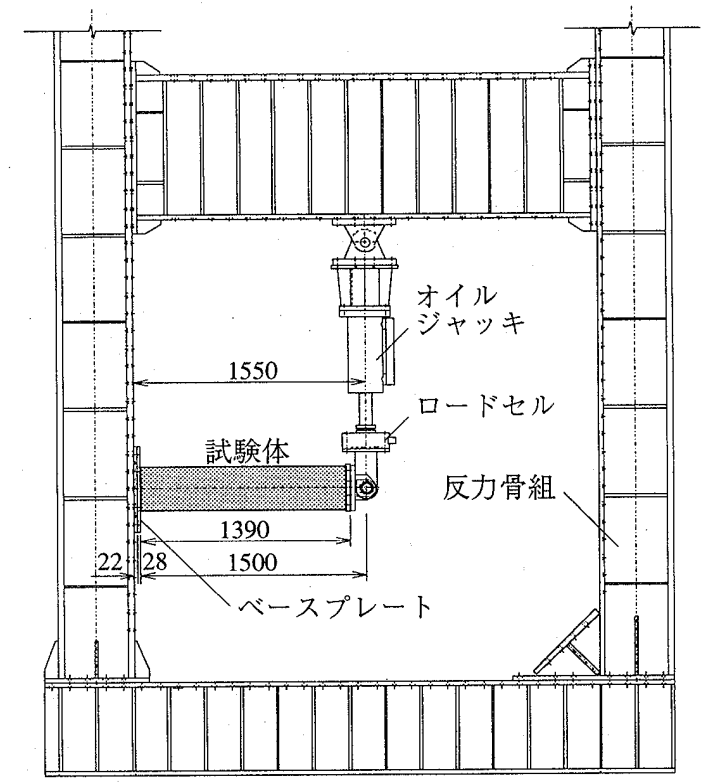

\begin{tabular}{|c|c|c|c|c|}
\hline \multicolumn{2}{|r|}{ 種別 } & $\begin{array}{c}\text { 降伏応力度 } \\
\mathrm{N} / \mathrm{mm}^{2}\end{array}$ & $\begin{array}{c}\text { 引張强さ } \\
\mathrm{N} / \mathrm{mm}^{2}\end{array}$ & $\begin{array}{l}\text { 役び } \\
\%\end{array}$ \\
\hline \multicolumn{2}{|c|}{ 規格：SS400 } & 235 & 400 & 17 \\
\hline \multirow{2}{*}{$3.2 \mathrm{~mm}$} & ミルシート & 340 & 442 & 39 \\
\hline & 材料引張試験 & 368 & 475 & 38 \\
\hline \multirow[t]{2}{*}{$2.3 \mathrm{~mm}$} & ミルシート & 307 & 451 & 35 \\
\hline & 材料引張試験 & 372 & 486 & 30 \\
\hline
\end{tabular}

因 3 試験体および試験装置概要

表 1 材料引張試験結果

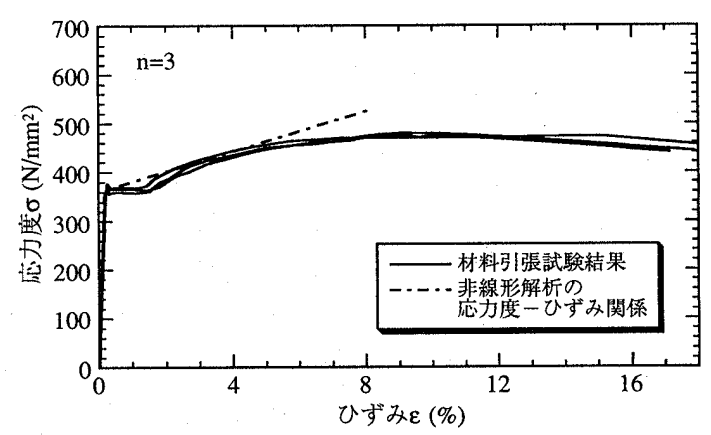

図 4 材料引張試験 応力度一ひずみ関係 $(\phi 300 \times 3.2)$

は，規格值で評価すると $9.35(\phi 300 \times 3.2)$ と $6.72(\phi 300 \times 2.3)$ で あり，非対称座屈は生じない領域となっている。

表 1 にJIS Z 2241により実施した当該部材の材料引張試験結果 (試 験片はJIS Z 22015 号試験片, 溶融亜鉛めっき後試験片切り出し）を 示す。降伏応力度は規格值と比較して 1.6 倍程度となっている。図 4 は $\phi 300 \times 3.2$ 鋼管の材料引張試験の応力度一ひずみ関係を示す。図 中の実線は試験結果であり,一点鎖線は次章で設定する非線形解析に おけるバイリニア型の応力度一ひずみ関係を表す。本研究では, 耐力 を求めることを主眼としており, 変形能力を検討する場合のように大 変形領域を対象としていないため, 応力度一ひずみ関係の 2 次勾配 は，降伏点からひずみ硬化域に引いた接線の傾きとした。

\section{2 載荷および計測方法}

載荷は $200 \mathrm{kN}$ オイルジャッキを用い, 荷重值は試験体とオイル ジャッキの中間部に設置されたロードセルにより検出する。変位量 は, 載荷点にワイヤーを介して, 反力骨組に固定されたバネ式変位計 にて計測を行う。 


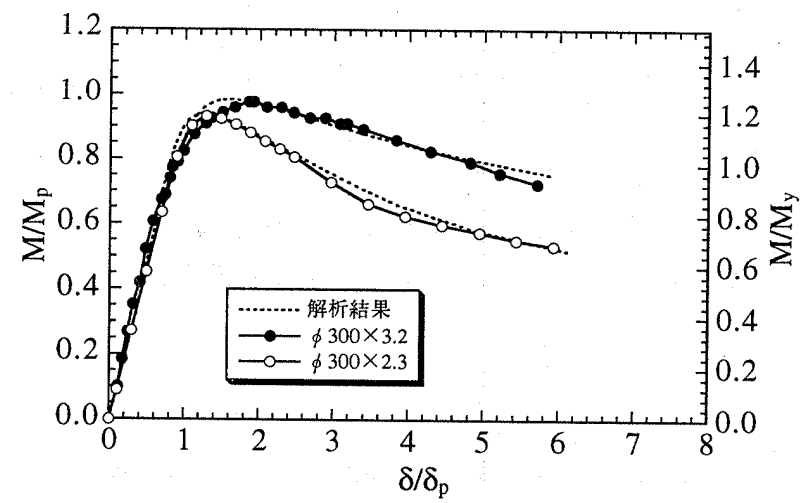

図 5 荷重一載荷部变位関係

表 2 試験結果一覧

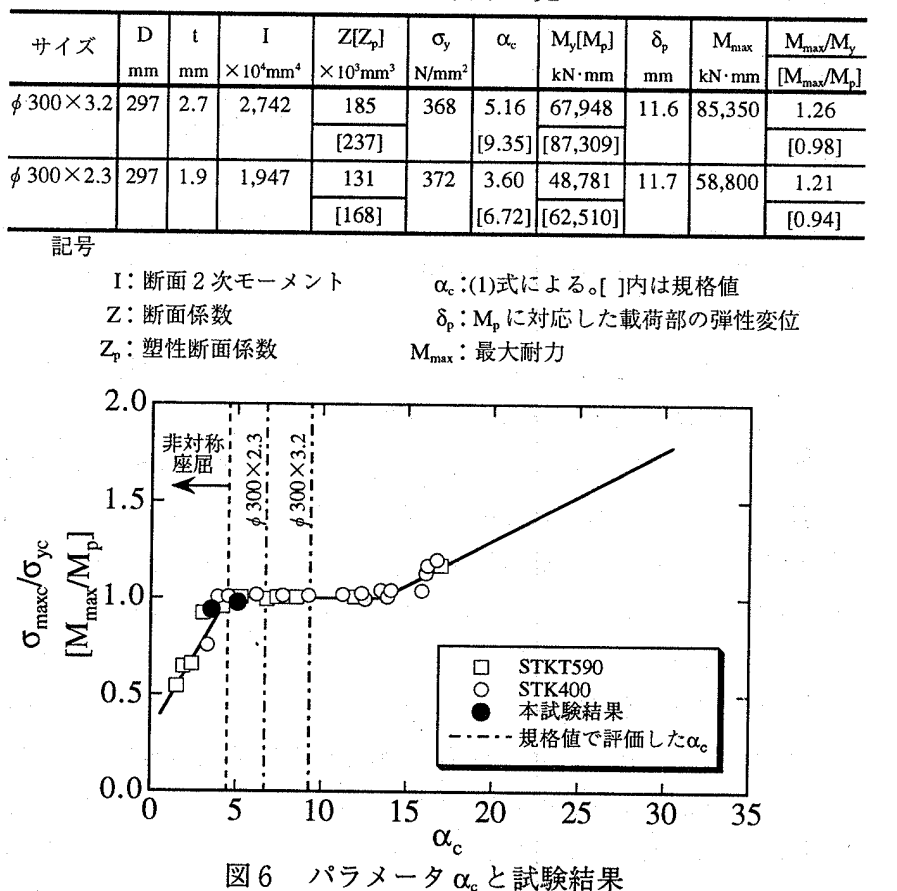

\section{3 試験結果}

図 5 に荷重一載荷部変位関係を示す。縦軸は曲げモーメント $\mathrm{M}$ を 全塑性モーメント $\mathrm{M}_{\mathrm{p}}$ (左軸)および降伏モーメント $\mathrm{M}_{\mathrm{y}}$ (右軸)で, 横 軸は載荷部変位 $\delta$ を $M_{p}$ に対応した載荷部弾性変位 $\delta_{\mathrm{p}}$ で無次元化して ある。印は $\phi 300 \times 3.2$, ○印は $\phi 300 \times 2.3$ であり, 点線は後述す る非線形解析結果を示す。試験結果を表 2 に示す。表中 2 段組となっ ている部分は, 上段は降伏モーメントに,下段は全塑性モーメントに 関連した值である。最大耐力は, 鋼構造設計規準の設計耐力 $\mathrm{M}_{\mathrm{y}}$ に対 して, $\phi 300 \times 3.2$ の場合は 1.26 倍, $\phi 300 \times 2.3$ の場合は 1.21 倍で あった。このように, 径厚比が大きいレベルにおいても, 降伏モーメ ント $\mathrm{M}_{\mathrm{y}}$ に対しては十分な余剩耐力があることが確認された。また,最 大耐力の $\mathrm{M}_{\mathrm{p}}$ に対する比率は，それぞれ $0.98 ， 0.94 て ゙ あ り$, 径厚比が 大きくなると $\mathrm{M}_{\mathrm{p}}$ に対する比率は低下した。また, 座屈モードはいず れも非対称座屈であった。最大耐力が $\mathrm{M}_{\mathrm{p}}$ を下回った理由は，文献 6 のパラメータ $\alpha_{c}$ と耐力上昇率を表した図 6 に示すとおり, 実降伏応 力度 (材料引張試験結果) が規格值に対して 1.6 倍であり，パラメー 夕 $\alpha_{\mathrm{c}}$ が小さくなり, 非対称座屈により屈服したためと考えられる。最 大耐力および最大耐力以後の変形挙動に関して試験結果と非線形解析 結果とは良い対応を示し, 解析手法の有効性が確認された。

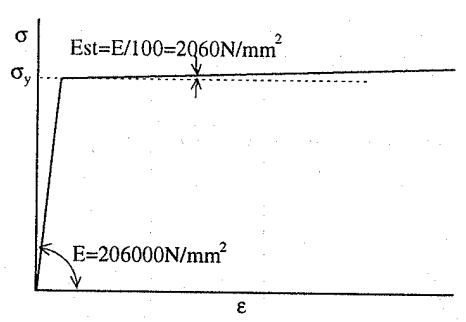

図 7 応力度一ひずみ関係

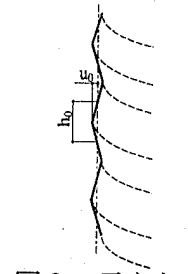

図 8 元たわみ

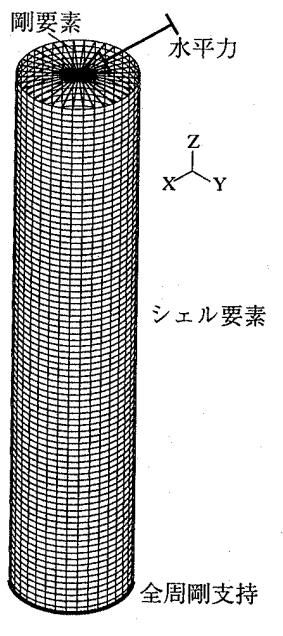

図 9 解析モデル（ $\phi 300 ）$

\section{3. 非線形解析による径厚比制限の検討 \\ 3. 1 解析検討概要}

本章では, 前章において有効性が確認された非線形解析手法を用い て, 径厚比をパラメータとしたケーススタディを行い, 全塑性モーメ ントを確保するための曲げモーメントを作用させた鋼管の径厚比制限 值の設定を行う。ここでは, 縮小部分モデル部材を基本とする。

\section{2 解析仮定条件}

解析仮定条件を以下に列挙する。

(1)本解析手法は材料および幾何学的非線形を考慮した複合非線形解 析である。

(2)部材はシェル要素を用いてモデル化する。なお, 模型骨組モデル においては, 柱朋部から全高さの $10 \%$ 高さの位置までをシェ ル要素とし，それより上部は梁要素にて置換する。

(3)材料特性について, 製管のままの鎆管は降伏点が現れないラウン ドハウス型となるが, 溶融亜鉛めっきを施した場合は降伏点が回 復するとの研究報告(7)があり, また, 図 4 と合わせて評価し, 図 7 に示すバイリニア型とする。ヤング係数等は図に示すとおりで ある。降伏応力度は規格值を用いる。なお, 試験模擬の解析にお いては，材料引張試験より得られた実降伏応力度とする。

(4)鋼管板要素の元たわみに関して, 鋼管の径厚比が大きい場合, 非 対称座屈が支配的となるが，ここでは，耐力的な指標を導き出す ことを目的としていることから, 次に示す簡便な方法で元たわみ を与える。元たわみの波形の半波長 $\mathrm{h}_{0}$ は圧縮力を受ける円筒シェ ルの弾性安定理論8 ${ }^{8}$ に基づく(2)式で表される座屈波形と仮定し, たわみ量 $\mathbf{u}_{0}$ は製作標準により製作時に許容される最大たわみ量で ある鋼管径の $0.25 \%$ とする。部材モデルは, 図 8 に示す元たわみ を有する部材軸まわりの回転体である。

$$
\mathrm{h}_{0}=1.22 \sqrt{\mathrm{D} \cdot \mathrm{t}}
$$

ここで, $\quad \mathrm{h}_{0}$ : 座屈波形の半波長 $(\mathrm{mm})$

(5)要素分割は, 材軸方向に関しては 1 要素長を座屈波形の半波と し, 周方向に関しては 36 分割とする。

なお，事前検討として， $\mathrm{D} / \mathrm{t}=100$ において，固有值解析による 座屈モードを元たわみとした解析を実施し,簡便な方法の最大耐 力が概ね一致することを確認している。 
表 3 解析モデル構造諸元

\begin{tabular}{c|c|c|c|c|c}
\hline $\mathrm{D} / \mathrm{t}$ & 75 & 100 & 125 & 150 & 300 \\
\hline $\mathrm{D}(\mathrm{mm})$ & 300 & 300 & 300 & 300 & 300 \\
\hline $\mathrm{t}(\mathrm{mm})$ & 4.0 & 3.0 & 2.4 & 2.0 & 1.0 \\
\hline \hline $\mathrm{I}\left(\times 10^{4} \mathrm{~mm}^{4}\right)$ & 4,074 & 3,087 & 2,484 & 2,079 & 1,050 \\
\hline $\mathrm{Z}_{\mathrm{p}}\left(\times 10^{3} \mathrm{~mm}^{3}\right)$ & 350 & 265 & 213 & 178 & 89 \\
\hline$\sigma_{\mathrm{y}}\left(\mathrm{N} / \mathrm{mm}^{2}\right)$ & 325 & 325 & 325 & 325 & 325 \\
\hline$\alpha_{c}$ & 8.45 & 6.34 & 5.07 & 4.23 & 2.11 \\
\hline $\mathrm{M}_{\mathrm{p}}(\mathrm{kN} \cdot \mathrm{mm})$ & 113,908 & 86,007 & 69,083 & 57,723 & 29,055 \\
\hline$\delta_{\mathrm{o}}(\mathrm{mm})$ & 10.31 & 10.28 & 10.26 & 10.25 & 10.21 \\
\hline
\end{tabular}

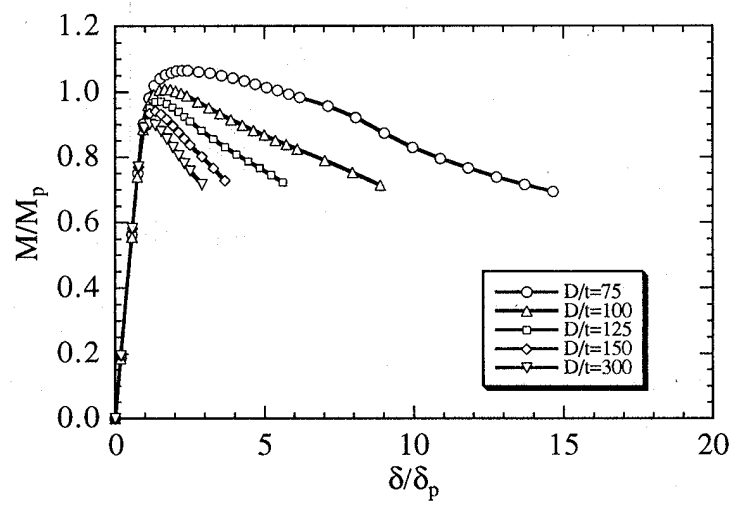

図 10 解析結果（荷重一水平变位関係）

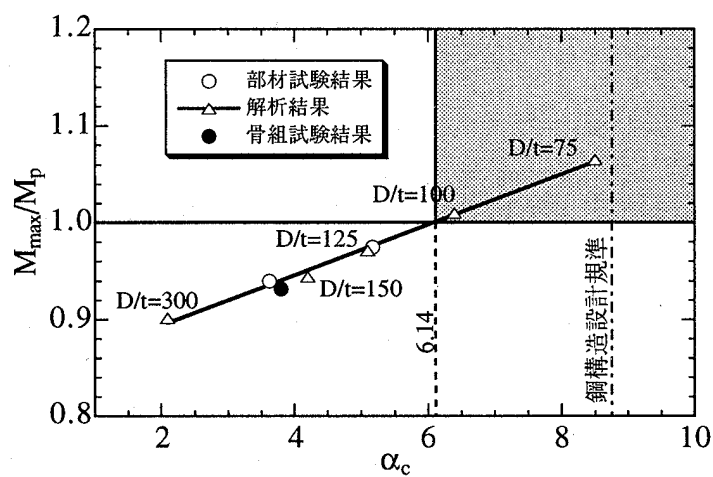

図 11 パラメータ $\alpha_{c}$ と最大耐力の関係

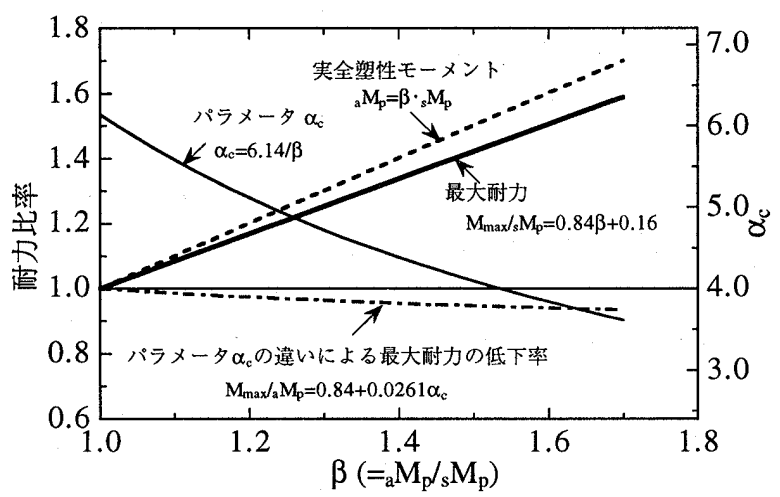

図 12 降伏応力度の上昇率 $\beta$ と最大耐力の関係

\section{6支持部境界条件は全周に渡り剛とする。}

上記仮定条件（材料特性のモデル化は除く）を用いた解析方法の有 効性は 2 章において既に確認済みである。また，解析プログラムは， 沉用構造解析プログラムである「ADINA」を用いた。

\section{3 . 3 径厚比制限值の検討}

鋼管に圧縮力を加えた場合の局部座屈応力度 $\sigma_{\mathrm{cr}}$ は, Donnel19による 微少変形理論に基づき次式のように与えられている。

$$
\sigma_{\mathrm{cr}}=\frac{2 \mathrm{E}}{\sqrt{3\left(1-\mathrm{v}^{2}\right)}}\left(\frac{\mathrm{t}}{\mathrm{D}}\right)
$$

ここで, 、はポアソン比

局部座屈が降伏応力度に達するまで発生しないとすると,(3)式で $\sigma_{\mathrm{cr}}=\sigma_{\mathrm{y}}$ とおき, 径厚比の上限值を求めると次式となる。

$$
\frac{D}{t}=\frac{2 E}{\sigma_{y} \sqrt{3\left(1-v^{2}\right)}}
$$

この值は,残留応力等部材の不完全さが存在しない理想断面につい ての值であり，実際にはこれより低い值となることが知られている。

また, 鋼構造設計規準では, 圧縮力を受ける部材の径厚比制限值は 次式としている。

$$
\frac{\mathrm{D}}{\mathrm{t}} \leq \frac{23500}{\sigma_{\mathrm{y}}} \text { (SI 単位系) }\left\{\frac{\mathrm{D}}{\mathrm{t}} \leq \frac{240}{\sigma_{\mathrm{y}}}\right\} \text { (MKS 単位系) }
$$

上記の值は純圧縮力を受ける場合の制限值であり, 曲げモーメント が加わる場合には圧縮側と引張側が存在するため, 制限值は緩和でき ると考えられる。

本節では径厚比をパラメータとした非線形解析を実施し,曲げを受 ける場合の径厚比制限を定量的に求める。

解析モデルは図 9 に示すとおりであり,表 3 に各径厚比に対する構 造諸元を示す。なお，SM490を対象とするが，パラメータ $\alpha_{c}$ を用い て整理することにより他の材質に対しても適用できると考える。

径厚比をパラメータとした解析結果 (荷重一水平変位関係)を図 10 に示す。縦軸は脚部での曲げモーメント $M$ を全塑性モーメント $\mathrm{M}_{\mathrm{p}}$ で, 横軸は載荷部の水平変位 $\delta$ を $\mathrm{M}_{\mathrm{p}}$ に対応した弾性水平変位 $\delta_{\mathrm{p}}$ でそれぞ れ無次元化してある。 $\mathrm{D} / \mathrm{t}=75$ の最大耐力は全塑性モーメント $\mathrm{M}_{\mathrm{p}}$ に到 達しているが， $\mathrm{D} / \mathrm{t}=125 ， 150 ， 300$ では $\mathrm{M}_{\mathrm{p}}$ に達していない。また， $\mathrm{D} /$ $\mathrm{t}=100$ の最大耐力は $\mathrm{M}_{\mathrm{p}}$ と同程度となっている。

ここで,パラメータ $\alpha_{c}$ と最大耐力 $\mathrm{M}_{\max }$ の関係を図 11 に示す。 $\Delta$ 印 は解析結果であり，2 章の部材試験結果 ( ○印) と，5章の骨組試験 結果 (の印) と併せ示してある。図中の実線は, 最小二乗法により求 めた次式で表される解析結果の回帰直線である。

$$
\mathrm{M}_{\max } / \mathrm{M}_{\mathrm{p}}=0.84+0.0261 \alpha_{\mathrm{c}}
$$

パラメータ $\alpha_{c}$ が大きくなるに伴い最大耐力は増大する。これより， パラメータ $\alpha_{c}$ が 6.14 より大きい場合, 最大耐力は全塑性モーメント を越えることがわかる(網掛け部分)。この值は鋼構造設計規準の值 より小さくなっている。これは, 曲げ材を対象としていること, 溶融 亜鉛めっきを施した鋼管であることに起因寸ると考えられる。

一般に，径厚比の制限は次のような形で表される。

$$
\mathrm{D} / \mathrm{t} \leq \frac{\mathrm{k}}{\sigma_{\mathrm{y}}}
$$

ここで, $\mathrm{k}$ は係数である。よって,(1)式に $\alpha_{\mathrm{c}}=6.14$ を代入し,(7)式の 形で全塑性モーメントを確保するための径厚比制限值は次式となる。

$$
\left.\mathrm{D} / \mathrm{t} \leq \frac{33500}{\sigma_{\mathrm{y}}} \quad \text { (SI 単位系 }\right)
$$


さて,(8)式で設計された断面の最大耐力に対する降伏応力度の影響 を考える。径厚比が規格降伏応力度 ${ }_{s} \sigma_{y}$ を用いた $(8)$ 式の上限値である $\mathrm{D} / \mathrm{t}=33500 /{ }_{\mathrm{s}} \sigma_{\mathrm{y}}$ の断面に対して, 実降伏応力度 ${ }_{\mathrm{a}} \sigma_{\mathrm{y}}$ が $\beta \cdot{ }_{\mathrm{s}} \sigma_{\mathrm{y}}(\beta \geqq 1.0)$ で あるとする。実降伏応力度で評価した全塑性モーメントを ${ }_{\mathrm{a}} \mathrm{M}_{\mathrm{p}}$ (以降, 実全塑性モーメントと呼ぶ), 規格伏応力度で評価した全塑性モーメ ントを ${ }_{\mathrm{s}} \mathrm{M}_{\mathrm{p}}$ （以降，規格全塑性モーメントと呼ぶ）と表すと, ${ }_{\mathrm{a}} \mathrm{M}_{\mathrm{p}}=\beta$. ${ }_{s} M_{p}$ となり,(6)式は次のとおり変換される。

$\mathrm{M}_{\max } / \mathrm{a} \mathrm{M}_{\mathrm{p}}=0.84+0.0261 \alpha_{\mathrm{c}}$

$\left.\alpha_{\mathrm{c}}=\mathrm{E} /{ }_{\mathrm{a}} \sigma_{\mathrm{y}} \cdot \mathrm{D} / \mathrm{t}\right)$ を上式に代入して整理すると,

$$
\mathrm{M}_{\max } / \mathrm{M}_{\mathrm{p}}=0.84 \beta+0.16
$$

この関係を図示すると図 12 となる。横軸は降伏応力度の上昇率 $\beta$ とし, 細実線はパラメータ $\alpha_{c}$, 一点鎖線はパラメータ $\alpha_{c}$ を最 大耐力の低下率(6)' 式, 点線は実全塑性モーメント, 太実線は最大测 力(6)”式を表す。これより, 規格降伏応力度を用いて評価した(8)式 の上限值で設計された断面は, 降伏応力度が規格值より大きくなるこ とによりパラメータ $\alpha_{c}$ が小さくなり, 非対称座屈を起こす領域とな るが，座屈モードを限定せず，最大耐力に着目すると，規格全塑性 モーメント以上の耐力を確保できる。

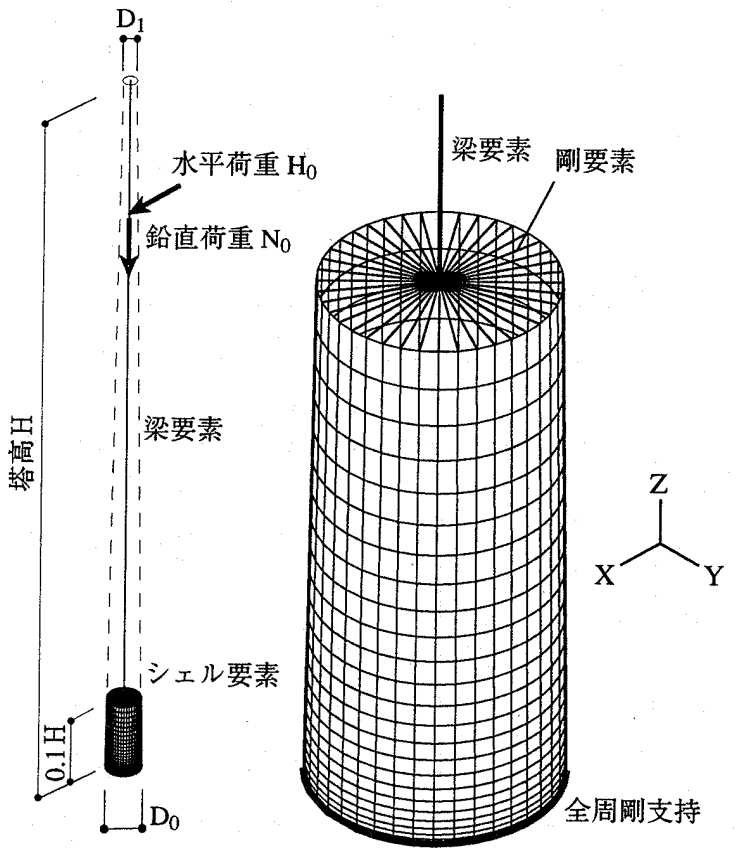

図 13 解析モデル（実規模）

表 4 解析モデル諸元諸元

\begin{tabular}{|c|c|c|c|}
\hline $\mathrm{H}(\mathrm{mm})$ & 40,000 & $\sigma_{\mathrm{y}}\left(\mathrm{N} / \mathrm{mm}^{2}\right)$ & 325 \\
\hline $\mathrm{D}_{0}(\mathrm{~mm})$ & 1,750 & $\mathrm{~N}_{\mathrm{y}}(\mathrm{kN})$ & 30,956 \\
\hline $\mathrm{D}_{1}(\mathrm{~mm})$ & 750 & $\mathrm{M}_{\mathrm{y}}(\mathrm{kN} \cdot \mathrm{mm})$ & $13,275,084$ \\
\hline$t_{0}(\mathrm{~mm})$ & 17.5 & $\mathrm{M}_{\mathrm{p}}(\mathrm{kN} \cdot \mathrm{mm})$ & $17,071,351$ \\
\hline $\mathrm{D}_{\mathrm{N} / \mathrm{t}_{0}}$ & 100 & $\mathrm{~N}_{0} / \mathrm{N}_{\mathrm{y}}$ & 0.054 \\
\hline $\mathrm{A}_{0}\left(\times 10^{2} \mathrm{~mm}^{2}\right)$ & 952 & $\mathrm{~N}_{0}(\mathrm{kN})$ & 1,672 \\
\hline $\mathrm{Z}_{90}\left(\times 10^{3} \mathrm{~mm}^{3}\right)$ & 40,846 & $\mathrm{M}_{0}(\mathrm{kN} \cdot \mathrm{mm})$ & $12,558,230$ \\
\hline $\mathrm{Z}_{\mathrm{p} 0}\left(\times 10^{3} \mathrm{~mm}^{3}\right)$ & 52,527 & $\mathrm{H}_{0}(\mathrm{kN})$ & 391 \\
\hline 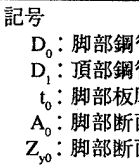 & 積 & $\begin{array}{r}\mathrm{Z}_{\mathrm{p} 0} \text { : 脚部塑 } \\
\mathrm{N}_{0}: \text { 基本鋁 } \\
\mathrm{M}_{0}:(8) \text { 式 } \\
\text { とした } \\
\text { 万曲 } \\
\mathrm{H}_{0} \text { : 基本水 }\end{array}$ & 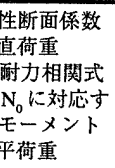 \\
\hline
\end{tabular}

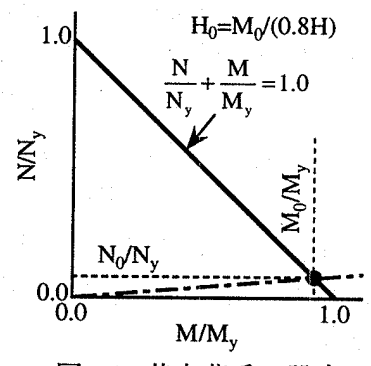

図 14 基本荷重の設定 (耐力相関図)

\section{4 ．鉄塔頂部の水平変位制限値の検討}

\section{1 検討概要}

水平荷重と鉛直荷重を受けた場合, 鉄塔頂部の水平変位 (以後, 頂 部水平変位と呼ぶ）が大きいと $\mathrm{P} \Delta$ 効果により所定の耐力を発揮でき ない恐れがある。そのため, 頂部水平変位の制限值も設定する必要が ある。ここでは, 既往鉄塔の調査結果に基づいて設定した平均的な規 模の実規模骨組モデルを対象に頂部水平変位制限値の検討を行う。

4. 2 解析条件

解析モデルは図13に示すと抢りであり，脚部付近（塔高の10\%）を シェル要素, 上部を梁要素とし, 境界部分は㴊要素で連結している。 脚部境界条件は全周に渡り剛とする。また, シェル要素部分の応力ー ひずみ関係はバイリニア型とし，材質はSM490を対象とする。上部 は載荷治具と考え弾性体とし, 塔高 $\mathrm{H}$ と頂部水平変位 $\Delta$ との比 $\Delta / \mathrm{H}$ を パラメータとするために, 上部梁要素の剛性を 0.5 倍から 5 倍の範囲 で変化させる。径厚比は, 図 11 よりパラメー夕 $\alpha_{c}$ が大きくなる(径 厚比 $\mathrm{D} / \mathrm{t}$ が小さくなる）と最大耐力は大きくなることから, 前章で設 定した径厚比制限の上限值である $\mathrm{D} / \mathrm{t}=100\left(\sigma_{\mathrm{y}}=325 \mathrm{~N} / \mathrm{mm}^{2}\right)$ とする。軸 力比は既存鉄塔の調査結果の最大值である $\mathrm{N} / \mathrm{N}_{\mathrm{y}}=0.054$ とする。ここ で, 軸力比は建築構造物と比較して小さい值であるが, 建築構造物で は層間変形角が通常 $1 / 200(0.5 \%)$ であるのに対して, 送電用鉄塔で は最大柎力時においては4〜6\%程度となることを考えると，P $\Delta$ 効果 は無視できないと言える。

表 4 に解析モデル構造諸元を示す。解析モデルは, 塔高を $\mathrm{H}$, 脚部 での鋼管径を $\mathrm{D}_{0}$, 頂部での鋼管径を $\mathrm{D}_{1}$ とし, その間は径厚比一定の 下, 直線的に鋼管径を減少させる。荷重載荷は, 水平・鉛直それぞれ 1 点に集約し，位置は，既存鉄塔調查に基づき，水平荷重は脚部での モーメントが実構造物と等しくなるように塔高の $80 \%$, 鉛直荷重は荷 重分布の重心である塔高の 70\%とした。図 14 に基本荷重の設定方法 を示す。基本鉛直荷重 $\mathrm{N}_{0}$ は，前述した軸力比に対応する値とし，耐 力相関式を(9)式とした場合の $\mathrm{N}_{0}$ に対応する曲げモーメントを $\mathrm{M}_{0}$ とす ると, 基本水平荷重 $\mathrm{H}_{0}$ は， $\left[\mathrm{M}_{0} /\right.$ 載荷高さ]で求める。解析は，基本 鉛直荷重, 基本水平荷重の比率一定のもと, 漸増載荷とする。

$$
\mathrm{N} / \mathrm{N}_{\mathrm{y}}+\mathrm{M} / \mathrm{M}_{\mathrm{y}}=1.0
$$

\section{3 鉄塔頂部水平変位制限值の設定}

図 15 は上部構造（図 13 梁要素）の曲げ凨性をパラメータとした荷 重一頂部水平変位関係を示す。剛性 1.0 倍は表 4 に示した構造諸元に

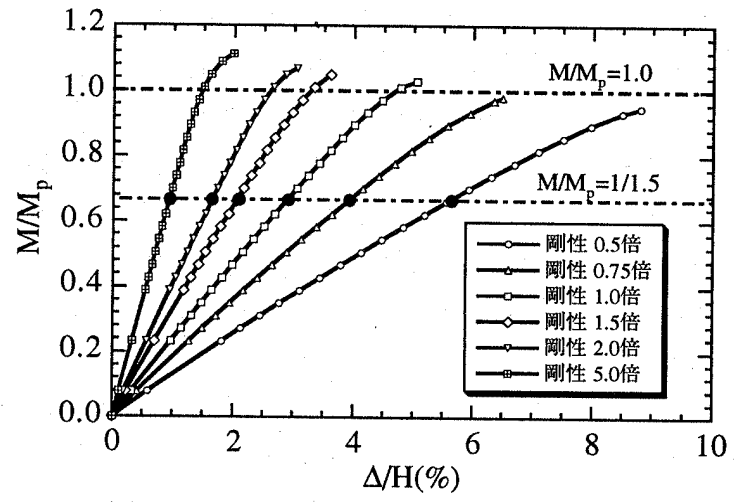

図 15 鉄塔剛性と荷重一頂部水平変位の関係 


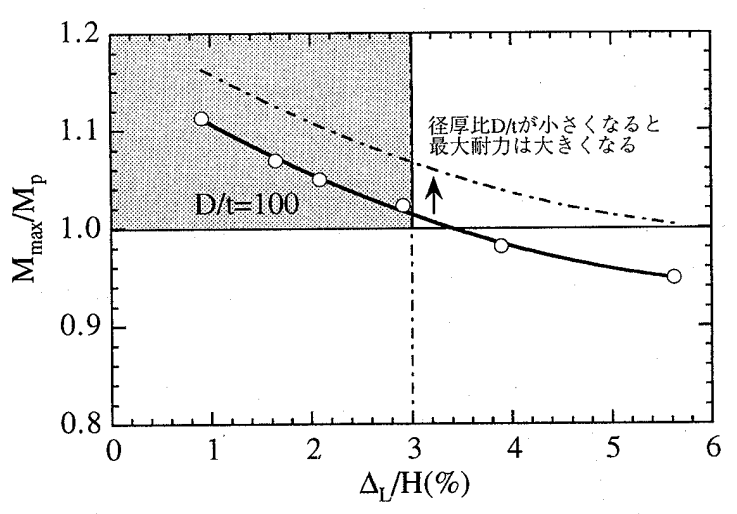

図 $16 \quad \mathrm{M} / \mathrm{M}_{\mathrm{p}}=1 / 1.5$ 時の頂部水平変位と最大耐力の関係

よる解析ケースであり，その他は上部構造の曲げ剛性を変化させた解 析ケースである。縦軸は脚部における曲げモーメント M を全塑性 モーメント $\mathrm{M}_{\mathrm{p}}$ で, 横軸は頂部水平変位 $\Delta$ を塔高 $\mathrm{H}$ で除している。頂 部水平変位が小さくなるに伴い最大耐力は大きくなっている。

ここで,設計時にその都度非線形解析を実施することは不経済であ るため，弾性範囲である全塑性モーメントの $1 / 1.5$ の耐力時において 変位の検証を行うことを考える。図中のの印は $\mathrm{M} / \mathrm{M}_{\mathrm{p}}=1 / 1.5$ 時に対す る各ケースにおける頂部水平変位 $\Delta_{\mathrm{L}}$ を示す。

図 16 は $\mathrm{M} / \mathrm{M}_{\mathrm{p}}=1 / 1.5$ 時の頂部水平変位と最大耐力との関係を示す。 図中の曲線は回帰曲線を示しており， $\Delta_{\mathrm{L}}$ が塔高 $\mathrm{H}$ のおよそ $3 \%$ 以内 であれば最大耐力は $\mathrm{M}_{\mathrm{p}}$ を上回る（網掛け部分）。よって， $\mathrm{M}_{\mathrm{p}}$ 確保の ための $\mathrm{M} / \mathrm{M}_{\mathrm{p}}=1 / 1.5$ 時頂部水平変位の制限値は次式となる。

$\Delta_{\mathrm{L}} / \mathrm{H} \leqq 3 \%$

\section{1/2スケール骨組座屈耐力試験}

\section{1 試験概要}

3 章および 4 章で検討した結果を確認するため，1/2 スケールの骨 組座屈耐力試験を行った。試験体の剛性は, 規格全塑性モーメントの $1 / 1.5$ 耐力時に塔頂部の変位が塔高の $3 \%$ となるように設計するが, 実 降伏応力度が規格降伏応力度より大きくなると, 実全塑性モーメント に対する1./1.5耐力時における変位が塔高の $3 \%$ を越え,(10)式の制限 值を満たさなくなり，P $\Delta$ 効果により耐力低下が懸念される。一方, 全 塑性モーメントの増大により, 最大耐力は増す。さらに, 部材試験と 同様，降伏応力度が大きくなると座屈モードも変化する。本試験は， これらが複雑に絡み合い, 試験結果について,それぞれの影響を明確 に分離して評価することは困難である。そこで, 本試験は, 最大耐力 および剛性に着目した非線形解析手法の妥当性検証を目的とする。

試験骨組は，既存鉄塔調査結果の平均的な規模の $1 / 2$ に相当する図 17に示すような形状寸法とし, 中間部に鋼管継手であるリブ付板フラ ンジ（引張ボルト接合, 以後, フランジ継手と呼ぶ）を設け, 載荷は, 電線風圧荷重 $\mathrm{Hc}$, 鉄塔風圧荷重 $\mathrm{Ht}$ を模擬した水平荷重抢よび電線重 量 V等を模擬した鉛直荷重を作用させる。図 18 は次項で想定する比 率で荷重を作用させ，脚部における応力が全塑性モーメント $\mathrm{M}_{\mathrm{p}}$ とな る場合の各部位における応力（1)）と全塑性モーメント $\mathrm{M}_{\mathrm{p}}$ (2) と の比の高さ方向分布を表す。これより，座屈が想定される部位は脚部 から下のフランジ継手の間であることがわかる。脚部と下のフランジ 継手の中間部 $(\mathrm{A}$ 部)における径厚比 $\mathrm{D} / \mathrm{t}$ はそれぞれ128，110である。

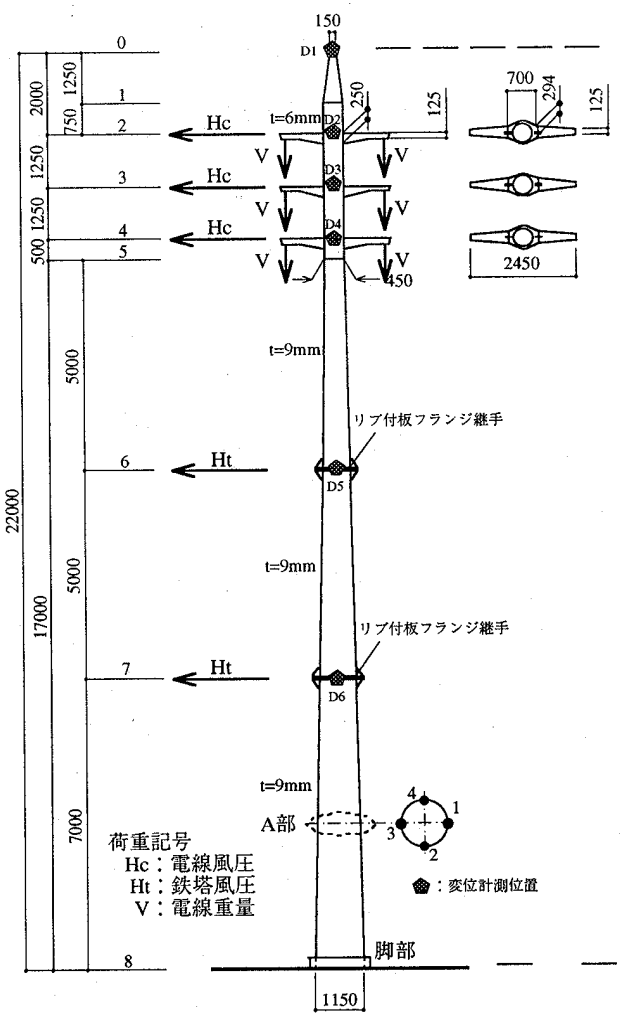

図 17 試験体概要図
(1) $/(2)$

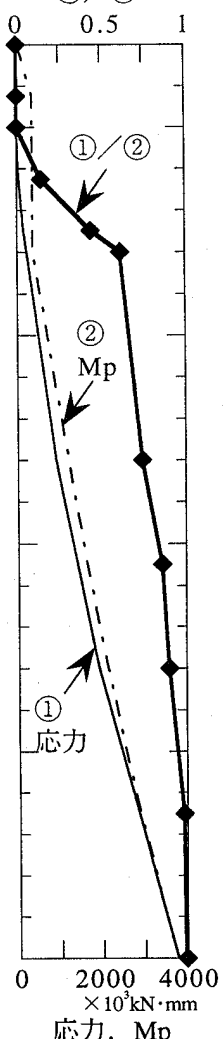

図 18 応力 $/ \mathrm{Mp}$
表 5 材料試験結果

\begin{tabular}{|c|c|c|c|}
\hline 種別 & $\begin{array}{c}\text { 降伏惢力度 } \\
\mathrm{N} / \mathrm{mm}^{2}\end{array}$ & $\begin{array}{c}\text { 張強 } \\
\mathrm{N} / \mathrm{mm}^{2}\end{array}$ & $\begin{array}{c}\text { 伸び } \\
\%\end{array}$ \\
\hline 規梠:SM490 & 325 & 490 & 17 \\
\hline ミルシート & 427 & 547 & 25 \\
\hline 材料引張試験 & 427 & 560 & 36 \\
\hline
\end{tabular}

表 6 試験体断面性能表

\begin{tabular}{|c|c|c|c|c|c|c|c|c|c|}
\hline \multirow[b]{2}{*}{ No. } & \multirow{2}{*}{$\begin{array}{c}\text { 商さ } \\
\text { H } \\
\text { mm }\end{array}$} & \multicolumn{8}{|c|}{ 断面性能 } \\
\hline & & $\begin{array}{c}\mathrm{D} \\
\mathrm{mm}\end{array}$ & $\begin{array}{c}\mathrm{t} \\
\mathrm{mm}\end{array}$ & $\overline{\mathrm{D} / \mathrm{t}}$ & $\begin{array}{c}\mathrm{A} \\
\times 10^{2} \mathrm{~mm}^{2} \\
\end{array}$ & $\begin{array}{c}\mathrm{Z} \\
\times 10^{3} \mathrm{~mm}^{3} \\
\end{array}$ & \begin{tabular}{|c|}
$\mathrm{Zp}$ \\
$\times 10^{3} \mathrm{~mm}^{3}$ \\
\end{tabular} & $\begin{array}{r}\mathrm{N} \\
\times 10^{3} \mathrm{k} \\
\end{array}$ & $\mathrm{J} \cdot \mathrm{mm}^{3}$ \\
\hline$\overline{\overline{0}}$ & 22,000 & 150 & $\overline{6}$ & 25.0 & 27 & $\overline{94}$ & 124 & {$[40]$} & --- \\
\hline 1 & 20,750 & 450 & 6 & 75.0 & 84 & 917 & 1,183 & [384] & --- \\
\hline 2 & 20,000 & 450 & 6 & 75.0 & 84 & 917 & 1,183 & [384] & --- \\
\hline 3 & 18,750 & 450 & 6 & 75.0 & 84 & 917 & 1,183 & [384] & --- \\
\hline 4 & 17,500 & 450 & 6 & 75.0 & 84 & 917 & 1,183 & [384] & $\ldots$ \\
\hline 5 & 17,000 & 450 & 6 & 75.0 & 84 & 917 & 1,183 & [384] & -- \\
\hline 6 & 12,000 & 656 & 9 & 72.9 & 183 & 2,918 & 3,766 & {$[1,224]$} & 1,608 \\
\hline 7 & 7,000 & 862 & 9 & 95.8 & 241 & 5,087 & 6,545 & {$[2,127]$} & 2,795 \\
\hline 8 & 0 & 1,150 & 9 & 127.8 & 323 & 9,131 & 11,717 & {$[3,808]$} & 5,003 \\
\hline
\end{tabular}

また，材質はSM490であり，溶融亜鉛めっき処理を施す。

表 5 に JIS Z 2241 に則り実施した当該部材（板厚 $9 \mathrm{~mm}$ ）の材料引 張試験結果（試験片はJIS Z 22015 号試験片, 溶融亜鉛めっき後切り 出し）を示す。降伏応力度は規格値のおよそ1.3倍となっている。表 6 に試験骨組の各部位における断面性能を示す。

\section{2 載荷および計測方法}

荷重は，既存鉄塔の調査結果に基づき $\Sigma \mathrm{Hc}: \Sigma \mathrm{Ht}: \Sigma \mathrm{V}=2: 3: 1$ の 比率で漸増载荷とし, 図 19 のとおり, 反力鉄塔を介してワイヤーウ インチ系で同時に載荷する。荷重値の検出は, 試験骨組側に配した ロードセルにより行い, 試験骨組各部の変位は光学変位計により,ひ ずみは一軸ひずみゲージにより計測する。載荷状況を写真 1 に示す。 


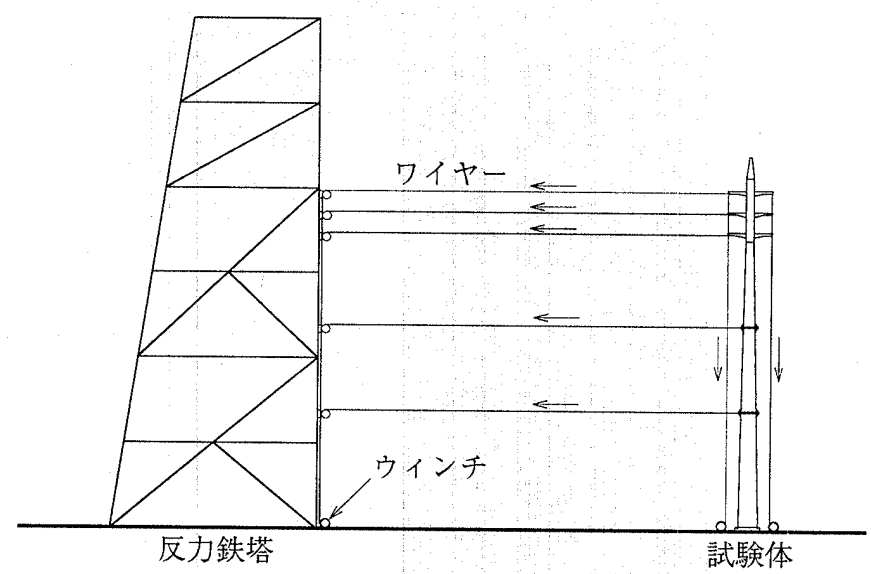

図 19 載荷方法

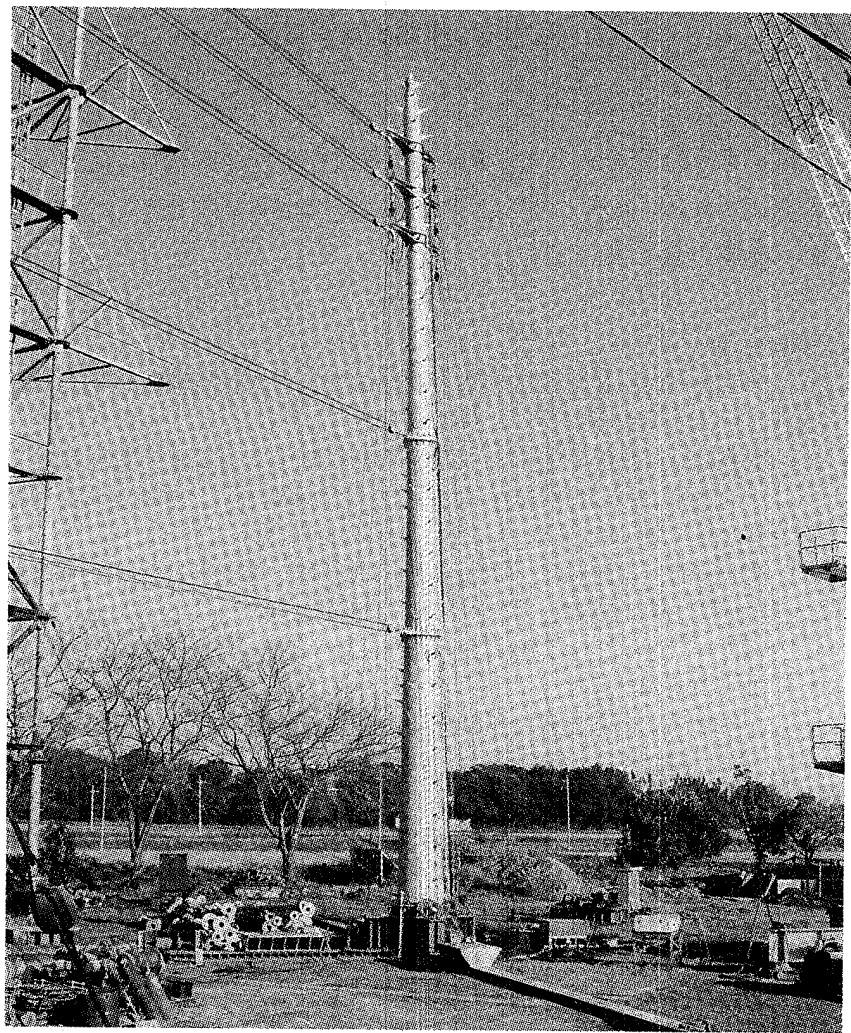

写真 1 載荷状況

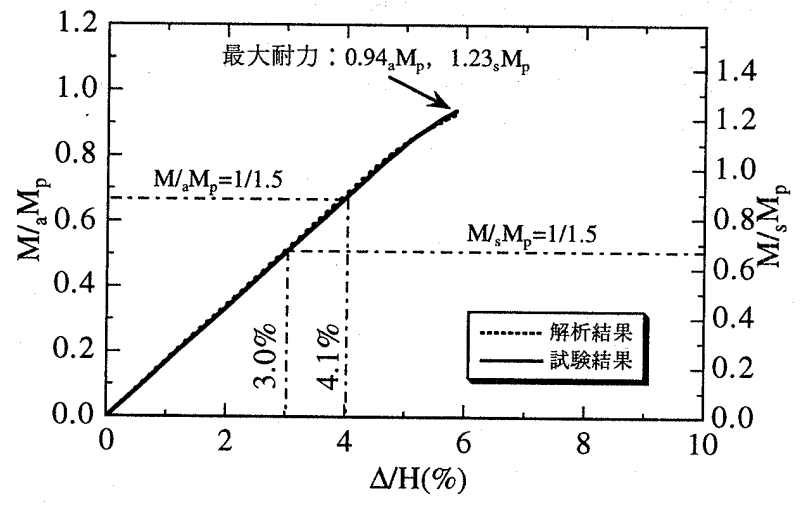

図 20 荷重一頂部水平変位関係

\section{3 試験結果}

図 20 に試験結果の荷重と頂部水平変位関係を示す。縦（左）軸は 脚部における曲げモーメント $M$ を実全塑性モーメント ${ }_{\mathrm{a}} \mathrm{M}_{\mathrm{p}}$ (右軸は規 格全塑性モーメント $\mathrm{S}_{\mathrm{p}}$ ) で無次元化した值を，横軸は鉄塔頂部の水 平変位 点線は前章で設定したシェル要素を用いた非線形解析結果を示す。な お，骨組座屈酎力試験は，柱脚部を鉄骨架台にアンカーボルトにより 定着させる方法を採っており,アンカーボルトの伸びによる柱脚部の 固定度の低下が懸念されたため,非線形解析ではアンカーボルトを等 価な断面積を有する鋼管部材に置き換え解析を行っている。実鉄塔は アンカーボルトがコンクリートにより根巻きされており, 脚部の固定 度は高いと考える。図より, 非線形解析結果は最大耐力, 変形挙動と もに試験結果と良い対応を示している。実全塑性モーメントの 1/1.5 耐力時での頂部水平変位は塔高の $4.1 \%$ となっており, 最大耐力は設 計時に要求される規格全塑性モーメントに対しては1.23倍であった。

図 21 は, 載荷荷重が $\mathrm{M} / \mathrm{s} \mathrm{M}_{\mathrm{p}}=0.05,0.25,0.5,1.0,1.1,1.2$ の場合 の変形モードをそれぞれ示す。図中の記号（D1～D6）は図 17 に示 した測定点位置の記号を表す。縦軸は変位計測点の高さ, 横軸は塔高 $H$ に対する各部位の水平变位 $\Delta_{\mathrm{i}}$ の比率を示す。実線は試験結果, 点線 は非線形解析結果である。試験結果と解析結果は概ね一致している。

図22に荷重と座屈部位（図17のA部）のひずみの関係を示す。図 中の数字はひずみゲージ番号を示し，1は引引張側，3は圧縮側， 2 と 4 は中立軸位置のひずみゲージである。降伏ひずみは $2073 \mu$ であり, 初期段階はほほ弾性的に推移し, 圧縮側のひずみが降伏ひずみを越え たあたりから剛性は低くなっている。また, 点線の解析結果と実線の 試験結果は荷重一ひずみ関係においても良い対応を示している。

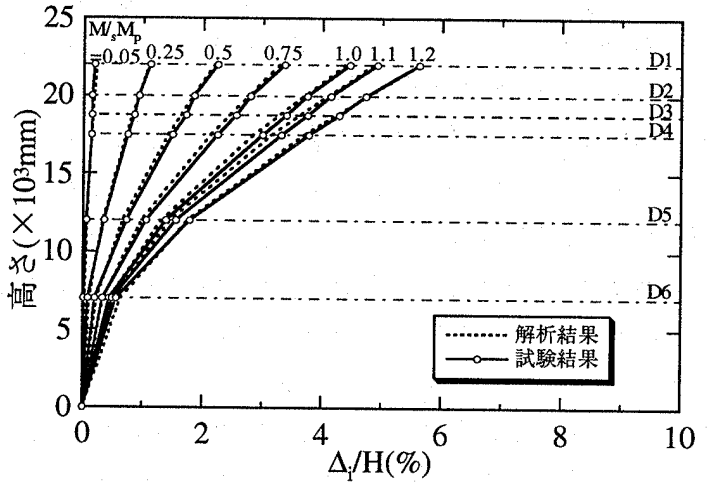

図 21 変形モード図

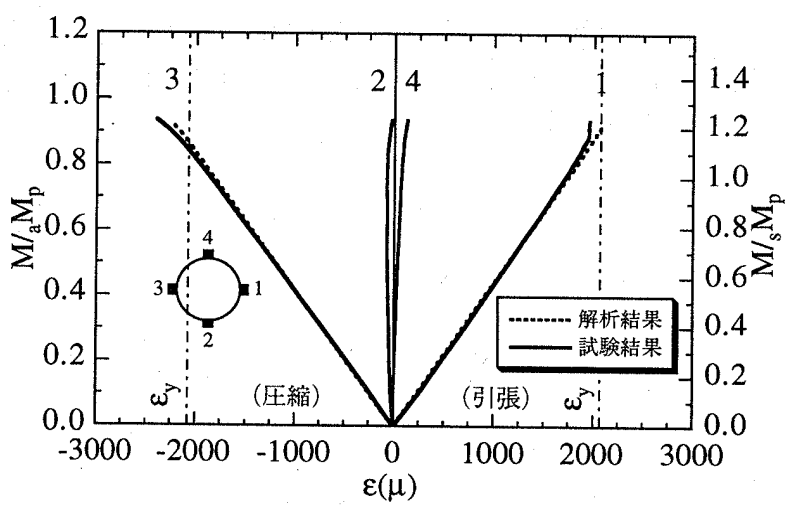

図 22 荷重一ひずみ関係 


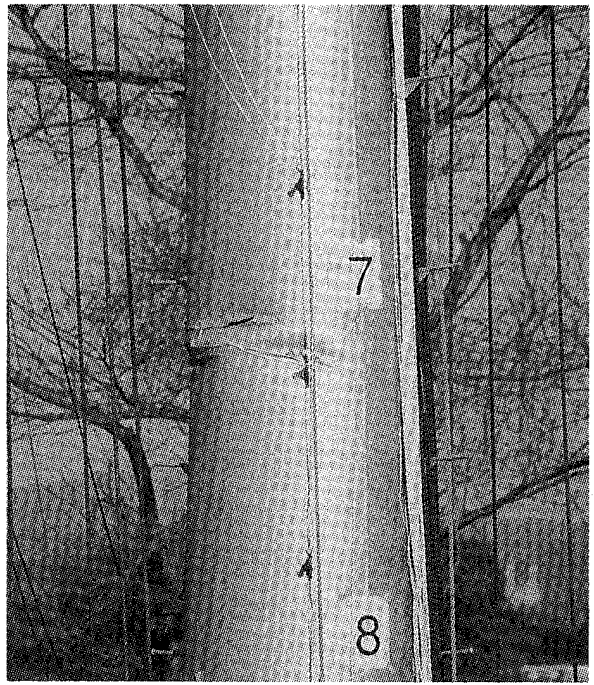

写真 2 座屈状況（側面）
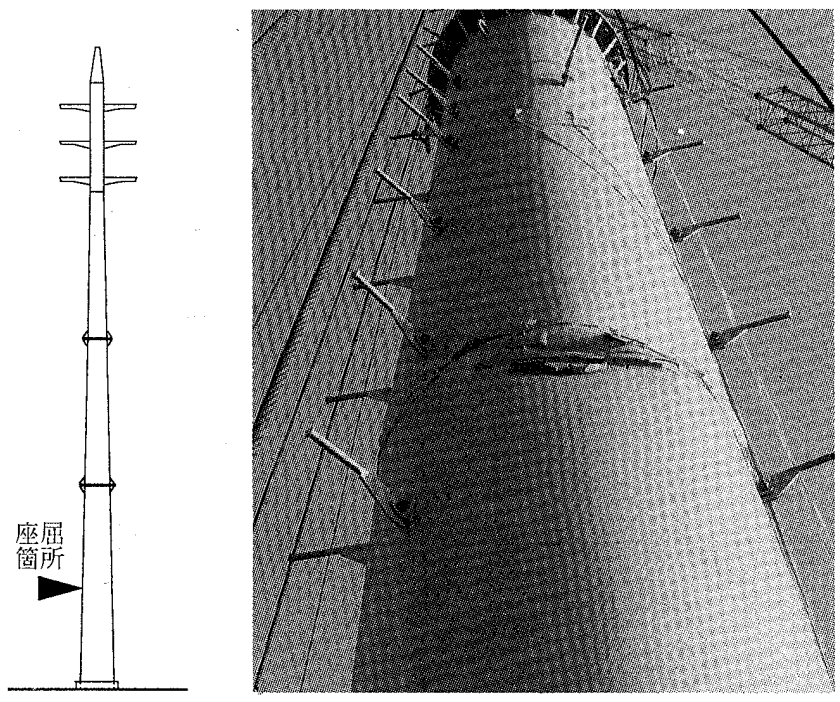

写真 3 座屈状況. (正面)
写真 2,3 に座屈部位の写真を示す。座屈部位は最下部と下のフラ ンジ継手の中央部であり，非対称座屈の様相を呈している。

以上, 最大耐力, 荷重一塔頂部水平変位関係, 変形モードおよび荷 重一ひずみ関係について, 解析結果と試験結果が概ね一致することか ら, 本検討内容の有效性が確認された。

\section{6.まとめ}

めっき鋼管を対象とした送電用鋼管単柱鉄塔の座屈耐力に関する本 研究より得られた結果を以下に列挙する。

(1)縮小部分モデル部材曲げ酎力試験より, 現在設計で用いている降 伏モーメント $\mathrm{M}_{\mathrm{y}}$ に対しては，十分な余剩耐力があることが確認 され，荷重一変位関倸において，試験結果と元たわみを考慮し シェル要素を用いた非線形解析結果とは良い対応を示した。

(2)有効性が確認された非線形解析手法を用いて,曲げモーメントが 作用した場合の全塑性モーメントを確保し得る径厚比制限の検討 を行った結果，制限值として D/t $\leqq 33500 / \sigma_{\mathrm{y}}$ が得られた。

(3)非線形解析より, 頂部水平変位と最大耐力の関係を明らかにし, 全塑性モーメントを確保するための $1 / 1.5 \mathrm{M}_{\mathrm{p}}$ 時における頂部水平 変位の制限値として， $\Delta_{\mathrm{I}} / \mathrm{H} \leqq 3 \%$ が得られた。

(4) 1/2 スケール骨組座屈耐力試験において, 非線形解析結果は最大 耐力, 変形挙動, 荷重一ひずみ関係について試験結果と良い対応 を示しており,骨組座屈耐力試験からも本研究における検討内容 の有効性が確認された。なお, 最大耐力は, 設計時に要求される 規格全塑性モーメントに対しては1.23倍であり,十分な耐力を有 していることを確認した。

\section{謝辞}

本研究を行うにあたり, 名古屋工業大学小野徹郎教授, 神奈川大学 大熊武司教授, 信州大学中込忠男教授の御指導を戴きました。ここに 深く感謝の意を表します。

\section{参考文献}

1）安生晃一郎：環境調和鉄塔の強度試験, 日本鉄塔協会鐵塔, 30 号, pp.1 17，1974年4月

2) 鈴木敏郎, 佐藤宣宏, 深沢隆 : 塔状鋼管卜ラス骨組の座屈耐力に関 する研究 細長比の小さい柱材で座屈する場合, 日本建築学会構造系 論文報告集，第425号，pp.69～81，1991年7月

3 ）鈴木敏郎, 小河利行, 佐藤宣宏, 樑沢隆 : 塔状鋼管トラスス骨組の座 屈耐力に関する研究（その 2) 端部せん断ボル卜接合された斜材の 座屈する場合, 日本建築学会構造系論文報告集, 第434号, pp.125 $135 ， 1992$ 年 4 月

4 ）越智健之, 最相元雄, 黑羽啓明 : 円形鋼管部材の曲げ耐力と変形能 力, 日本建築学会九州支部研究報告, 第28号, pp.309 312, 1985年 3 月

5）日本建築学会, 鋼構造設計規準, 1970年

6) 鈴木敏郎, 佐藤宣宏, 深沢隆 : 溶融亜鉛めっき鋼管の圧縮変形性状 に関する研究, 日本建築学会構造系論文報告集, 第420号, pp.51 61 ，1991年2月

7 ) 本郷榮次郎, 小川正浩, 山崎智之, 深沢隆, 松尾康博, 石田交広: 鋼管の溶融亜鉛めっきによる降伏応力度上昇に関する研究（その1） , 日本建築学会大会学術講演集C-1, pp.357～358，1999年9月

8 ) Timoshenko, S.P. and Gere, J.M. : Theory of Elastic Stability Second Edition, pp.457 485, McGRAW-HILL KOGAKUSHA

9 ) Donnell, L. H. : A New Theory for the Buckling of Thin Cylinders under Axial Compression and Bending. Trans, A.S.C.E., Vol. 56. pp.795 806, 1934 